\title{
Using mariculture as a breeding site: reproduction of Hypleurochilus fissicornis (Actinopterygii: Blenniidae)
}

\author{
Bianca Possamai ${ }^{1,2}$, Luís Fernando Fávaro ${ }^{1}$ \\ ${ }^{1}$ Laboratório de Reprodução e Comunidade de Peixes, Setor de Ciências Biológicas, Depto de Biologia Celular. Centro \\ Politécnico, Universidade Federal do Paraná (UFPR), Caixa Postal 19031. Rua Francisco H. dos Santos, s/n. Curitiba, PR, \\ Brasil. CEP 81531-990 E-mail: (BP) biancapossamai@ hotmail.com; (LFF) lufavaro@ufpr.br. \\ ${ }^{2}$ Programa de Pós-Graduação em Ecologia e Conservação, Setor de Ciências Biológicas, Centro Politécnico, Universidade \\ Federal do Paraná (UFPR), Caixa Postal 19031, Rua Francisco H. dos Santos, s/n. Curitiba, PR, Brasil CEP 81531-990.
}

\begin{abstract}
Summary: Mariculture in estuaries provides substrate for colonization by fouling organisms, thus attracting small cryptic fish species hitherto unknown in this environment. The blenny Hypleurochilus fissicornis is one of the species that is associated with this new system and is found in high abundance in bivalve farming. To understand the reproductive strategy that this species uses in this new environment, we collected specimens monthly in a mariculture on the southern coast of Paraná State (Brazil). After obtaining morphometric data, we removed gonads to determine sex and maturity stage. Gonads were weighed and analysed histologically. Oogenesis showed the same pattern as in other teleosts, but spermatogenesis showed a very complex dynamics. The spawning is multiple and synchronous between sexes, lasting eight months (May to December) and peaking in winter. Hypleurochilus fissicornis was reproductively successful using the mariculture as a breeding site. The species has a variety of tactics to protect its offspring (e.g. batch spawning, long reproductive period, reduced $\mathrm{L}_{50}$, parental care and a reproductive peak in winter).
\end{abstract}

Keywords: gametogenesis; histology; reef fish; parental care.

El uso de la maricultura como sitio de reproducción: reproducción de Hypleurochilus fissicornis (Actinopterygii: Blenniidae)

Resumen: La práctica de la maricultura en estuarios porporciona el sustrato necesario para la colonización de organismos incrustantes, los cuales atraen a pequeños peces crípticos desconocidos hasta la fecha en este ambiente. El blénido Hypleurochilus fissicornis es una de las especies asociadas a estos nuevos sistemas, encontrándose en elevada abundancia junto al cultivo de bivalvos. Con el objeto de entender la estrategia reproductiva que esta especie usa en su nuevo ambiente, se muestrearon mensualmente especímenes en una instalación de maricultura en la costa sur del estado de Paraná (Brazil). Después de obtener los datos morfométricos, las gónadas fueron extraídas para determinar el sexo y el estado de madurez. Las gónadas fueron pesadas y analizadas histológicamente. La ovogénesis presentó el mismo patrón que otros teleosteos, mientras que la espermatogénesis presentó una dinámica compleja. La puesta es múltiple y sincrónica entre sexos, extendiéndose durante ocho meses (de mayo a diciembre), con un pico de puesta en invierno. Hypleurochilus fissicornis tuvo una reproducción exitosa empleando las instalaciones de maricultura como zona de cría. Dicha especie presentó una variedad de tácticas para proteger su descendencia (p.ej. desove en lotes, largos periodos de reproducción, $\mathrm{L}_{50}$ reducida, cuidado parental y pico de puesta invernal).

Palabras clave: gametogénesis; histologia; peces de arrecife; cuidado parental.

Citation/Como citar este artículo: Possamai B., Fávaro L.F. 2015. Using mariculture as a breeding site: reproduction of Hypleurochilus fissicornis (Actinopterygii: Blenniidae). Sci. Mar. 79(3): 335-343. doi: http://dx.doi.org/10.3989/ scimar.04176.19B

Editor: E. Mañanos.

Received: November 6, 2014. Accepted: May 29, 2015. Published: June 23, 2015.

Copyright: () 2015 CSIC. This is an open-access article distributed under the Creative Commons Attribution-Non Commercial Lisence (by-nc) Spain 3.0. 


\section{INTRODUCTION}

Fish inhabiting artificial reefs have demonstrated reproductive success similar to or better than that of those living in natural reefs, probably due to the greater protection offered by environments of anthropogenic origin (Granneman and Steele 2014). Maricultures are examples of artificial environments that offer protection and foraging resources for fish (Goodbrand et al. 2013).

Mariculture structures alter the environment, resembling a reef environment. This enables the occurrence of species formerly absent at the site (Freitas and Velastin 2010). In addition to cryptic fish species, other organisms such as corals, bryozoans, sponges and echinoderms are attracted to these new consolidated environments. They are mostly suspensivores, thus changing the suspended material and consequently the turbidity (Thrush and Dayton 2002).

Hypleurochilus fissicornis (Quoy and Gaimard, 1824) is a small-sized cryptic marine species that inhabits consolidated environments such as coral and rocky reefs. The species is distributed in the western Atlantic from Vitória (Espírito Santo State, Brazil) to Mar del Plata (Argentina) and in the northeast Atlantic in the Azores (Portugal) (Menezes and Figueiredo 1985, Santos et al. 1997, Floeter et al. 2003). As in other Blenniidae fish, males take care of the nest where females spawn oocytes. The preferential sites for nests of $H$. fissicornis are rock crevices, empty shells, barnacles and even experimental fouling panels (Menezes and Figueiredo 1985, Omena and Souza 1999).

Small organisms such as blennies have the potential to dominate resources and control the functions of the system in which they live in high abundances, performing a fundamental role in the trophic chain of reef en- vironments (Ackerman and Bellwood 2000). In natural coastal reefs and in artificial ones designed to increase local diversity, $H$. fissicornis is usually found in low abundances from northern Rio de Janeiro State to the south-central coast of Santa Catarina State (Brotto et al. 2007, Luiz-Jr. et al. 2008, Alves and Pinheiro 2011). On the other hand, in mariculture, the species is found in high abundances (Gerhardinger et al. 2004, Freitas and Velastin 2010), indicating that $H$. fissicornis probably reproduces more successfully in artificial sheltered environments than in natural coastal habitats.

Aiming to determine the strategy used by $H$. fissicornis in an artificial environment, the present study intended to (1) characterize the maturity stages of females and males from the development of germ cells (oogenesis and spermatogenesis), (2) identify the reproductive tactics to check for the reproductive success, and (3) investigate the use of cultivation structures in the reproductive process.

\section{MATERIALS AND METHODS}

Guaratuba Bay (Fig. 1) has an area of $50.19 \mathrm{~km}^{2}$ situated on the coastal plain of southern Brazil. The climate of the region is humid mesothermal. Data of air temperature and rainfall, furnished by the technological institute SIMEPAR, were used to characterize the study period. The highest mean monthly temperatures were recorded in January $\left(25.8^{\circ} \mathrm{C}\right)$, February $\left(26.1^{\circ} \mathrm{C}\right)$ and March $\left(24.1^{\circ} \mathrm{C}\right)$, and the lowest in July $\left(15.9^{\circ} \mathrm{C}\right)$ and August $\left(16.3^{\circ} \mathrm{C}\right)$. The mean annual temperature was $21.0^{\circ} \mathrm{C}$. Cumulative rainfall was $2020.6 \mathrm{~mm}$, with the largest volume in June $(220.2 \mathrm{~mm})$ and the smallest in August (77.4 mm).

Monthly samplings were conducted between May 2013 and May 2014, in an oyster (Crassostrea

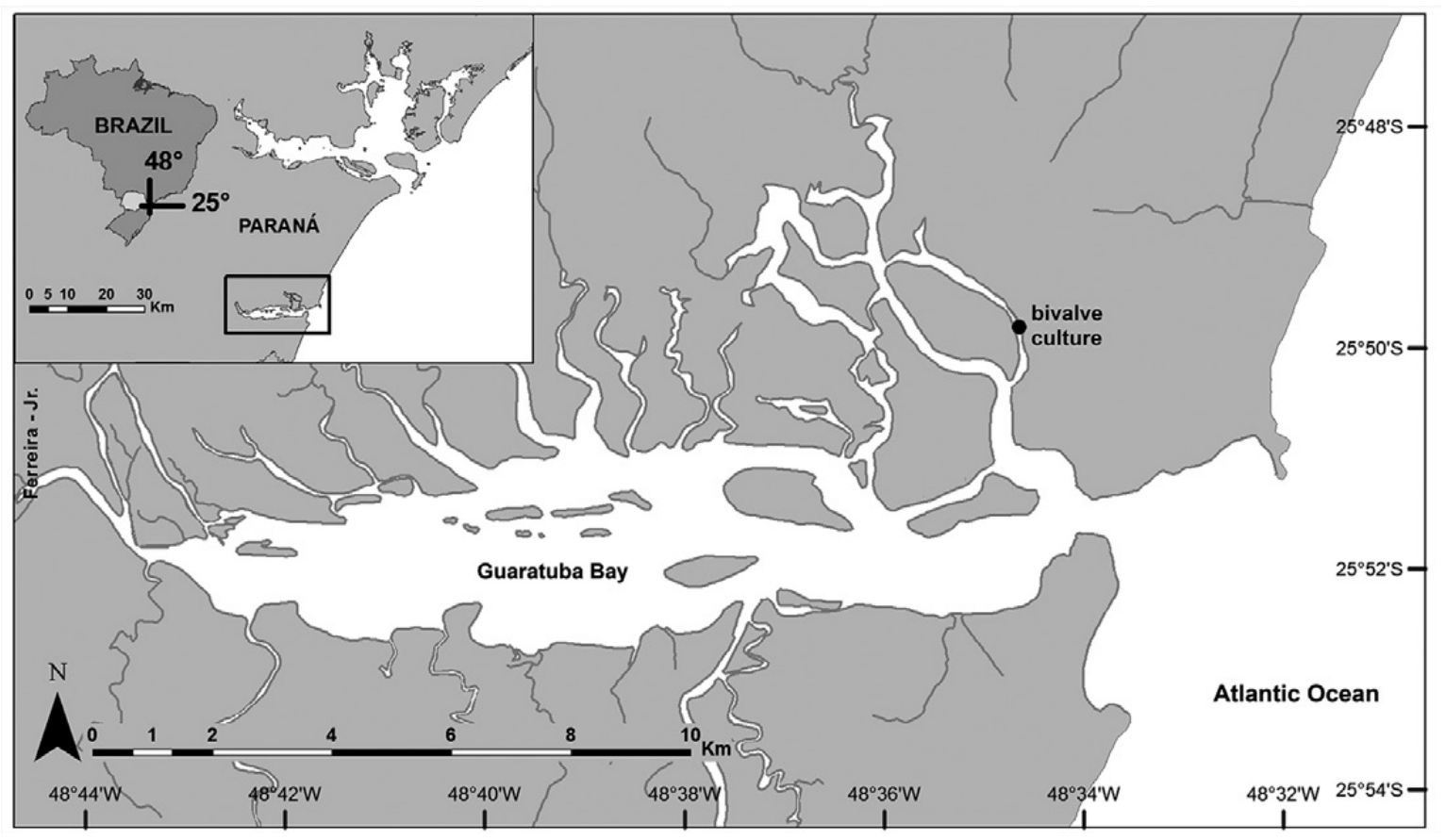

Fig. 1. - Guaratuba Bay (state of Paraná, Brazil). Cultivation of sampled bivalves (black dot). 
brasiliana (Lamarck, 1819)) farm in the Pinheiros River $\left(25^{\circ} 26^{\prime} \mathrm{S}\right.$; $\left.49^{\circ} 17^{\prime} \mathrm{W}\right)$, near the mouth of the bay. Oysters were placed in mesh tubes, which were attached to a main cable held above the water by floats. These mesh tubes were covered with a cylindrical net (mesh $1 \mathrm{~mm}$ ) by means of diving in order to prevent the escape of organisms, and brought to the surface following the methodology used by Freitas and Velastin (2010). Shells on which spawn was laid were also collected, as well as water temperature, $\mathrm{pH}$, dissolved oxygen (DO) and salinity data (obtained using a multiparameter probe).

In the laboratory, measurements of total length (TL in $\mathrm{cm}$ ) and total weight (TW in $\mathrm{g}$ ) of specimens of $H$. fissicornis were taken. Gonads were removed, weighed ( $\mathrm{GW}$ in $\mathrm{g}$ ) and identified macroscopically for sex and gonadal development (according to Vazzoler 1996 and Brown-Peterson et al. 2011). Some gonads were subjected to routine histological analysis (fixed in ALFAC for $18 \mathrm{~h}$ and embedded in Paraplast). Slides were stained with hematoxylin-eosin and analysed under a light microscope to characterize the maturity stage of females and males and to confirm the macroscopic identification of gonadal stages. The characterization of the development of female germ cells was based on Lowerre-Barbieri et al. (2013), while the maturity stage for females and males was prepared according to Vazzoler (1996) and Brown-Peterson et al. (2011). The sex ratio (monthly and by length classes) was analysed by a $\chi^{2}$ test, with a degree of freedom of 1 and a significance of $0.05\left(\chi^{2}>3.84\right)$, according to Vazzoler (1996). The length classes (seven classes with a $1-\mathrm{cm}$ range) were established in accordance with Sturges (Sokal and Rolf 1981).

The individual gonadosomatic index (GSI), expressed by the formula $\mathrm{GSI}=(\mathrm{GW} / \mathrm{TW}) 100$, was calculated to analyse gonadal development. To determine the maturation curve, the monthly mean GSI was calculated from the individual GSI of females and males, including juveniles of both sexes. After histological analysis of gonads, the distribution of the monthly percentage frequencies of gonadal development and the frequencies of young and adult individuals were estimated.

The weight-length relationship was calculated by $\mathrm{TW}=\mathrm{aTL}{ }^{\mathrm{b}}$, in which $\mathrm{a}$ is the linear coefficient and $\mathrm{b}$ is the slope (both determined using the least squares method) (Le Cren, 1951). From this, the total and somatic condition factors were calculated, expressed by $\mathrm{K}=\mathrm{TW} / \mathrm{TL}^{\mathrm{b}}$ and $\mathrm{K}^{\prime}=\mathrm{BW} / \mathrm{TL}^{\mathrm{b}}$, respectively $(\mathrm{BW}=$ body weight of the specimen subtracting the gonad weight).

Length at first maturity $\left(\mathrm{L}_{50}\right)$ was calculated by $\mathrm{Fr}=1-\left(\mathrm{e}^{-\mathrm{aL}_{\mathrm{m}} \mathrm{b}}\right) \quad(\mathrm{Fr}=$ relative frequency of adult individuals; $\mathrm{e}=$ base of the Napierian logarithm; $\mathrm{a}$ and $\mathrm{b}$ are coefficients estimated by the least squares method, transforming the variables involved; and $\mathrm{L}_{\mathrm{m}}=$ midpoint of the length classes), according to Fávaro et al. (2003) and Oliveira and Fávaro (2011) in reproductive studies on estuarine fish.

Abiotic variables were summarized by a principal component analysis (PCA). Axes with higher eigenvalues were used to relate with gonadal development stages through Spearman correlation $(\alpha=0.05)$. The

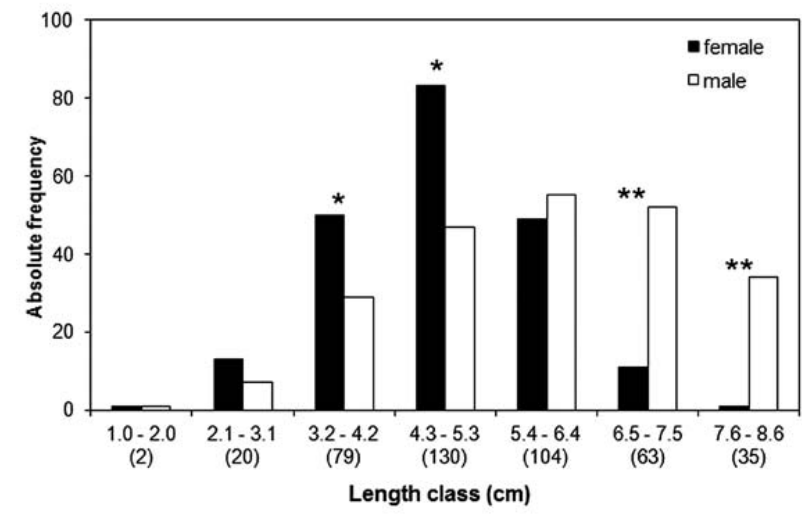

Fig. 2. - Frequency of $H$. fissicornis females and males in the length classes collected in a bivalve cultivation (state of Paraná, Brazil) between May 2013 and May 2014. Values in parentheses below the length classes indicate the number of individuals in the class. *pvalue $<0.05 ; * *$ p-value $<0.001$

broken-stick method was used to select the most important axes. The seasons of the year were defined as autumn (April to June), winter (July to September), spring (October to December) and summer (January to March). These analyses were run using the $\mathrm{R}$ 3.1.0 software.

\section{RESULTS}

A total of 519 specimens were collected from May 2013 to May 2014 (205 females, 228 males and 86 of unidentified sex, including juvenile and adults with TL ranging from 1.2 to $5.4 \mathrm{~cm}$ ). No specimens were collected in February and March 2014. TL varied from 2.0 to $7.8 \mathrm{~cm}(4.78 \pm 1.06 \mathrm{~cm})$ and from 2.0 to $8.5 \mathrm{~cm}$ $(5.64 \pm 1.50 \mathrm{~cm})$ for females and males, respectively.

There were no significant differences in the sex ratio between the months, except January, when a larger number of males was found $\left(\chi^{2}=4.89 ; \mathrm{df}=1 ; \mathrm{p}<0.05\right)$. The analysis of sex ratio by size classes showed differences between the sexes. Intermediate classes (3.2-4.2 and $4.3-5.3 \mathrm{~cm})$ were dominated by females $\left(\chi^{2}=5.12\right.$ and $\left.\chi^{2}=8.57 ; \mathrm{df}=1 ; \mathrm{p}<0.05\right)$ and the larger classes $(6.5$ 7.5 and $7.6-8.6 \mathrm{~cm})$ by males $\left(\chi^{2}=27.55\right.$ and $\chi^{2}=30.11$; $\mathrm{df}=1 ; \mathrm{p}<0.05)($ Fig. 2).

\section{Histological description of the gonads}

There were six developmental stages of ovarian follicles. Oogonia are the smallest germ cells, with a large nucleus and scant cytoplasm. The primary growth (PG) oocyte is characterized by increased cytoplasmic volume and basophilia. In the next stage, called cortical alveolar (CA), oocytes have vesicles in the cytoplasm. Subsequently, primary, secondary and tertiary vitellogenic oocytes (Vtg) have, in addition to these vesicles, yolk granules in the cytoplasm. In the next stage, oocytes with germinal vesicle migration (GVM) have larger diameter and cytoplasm filled by yolk granules. Then, pre-ovulatory hydration promotes the fusion of yolk granules, characterizing the hyalinization process and the germinal vesicle breakdown oocytes (GVBD). Follicle cells are squamous in the PG oocytes, which 
Table 1. - Maturation scale of Hypleurochilus fissicornis females in a bivalve cultivation (state of Paraná, Brazil). Scale adapted from Vazzoler (1996), Brown-Peterson et al. (2011) and Lowerre-Barbieri et al. (2013). Oocyte abbreviations: PG, primary growth; CA, cortical alveolar; Vtg, primary, secondary and tertiary vitellogenic; GVM, germinal vesicle migration; POF, post-ovulatory follicle; GVBD, germinal vesicle breakdown.

\begin{tabular}{ll}
\hline $\begin{array}{l}\text { Stage of gonadal } \\
\text { development }\end{array}$ & \multicolumn{1}{c}{ Microscopic characteristics } \\
\hline Immature & $\begin{array}{l}\text { Only young females possess this stage. Characteristics of the immature ovaries: oogonia and PG follicles are } \\
\text { well-organized in the ovigerous lamellae. This stage does not present follicles in vitellogenesis. }\end{array}$ \\
Developing & $\begin{array}{l}\text { At the beginning of this stage the females are considered adults entering the reproductive cycle. Characteristics: } \\
\text { oogonia, PG oocytes, CA oocytes and, in lower concentrations Vtg oocytes are present. Follicles with CA and PG } \\
\text { cells are predominant. As maturation progresses, the quantity of Vtg oocytes increases. }\end{array}$ \\
Spawning-capable & $\begin{array}{l}\text { Follicles with GVM cells. Follicles with PG and Vtg oocytes are found in smaller number. } \\
\text { Partially-spawned }\end{array}$ \\
$\begin{array}{l}\text { Occurs only in species that spawn in batches. Characteristics: Abundant POFs and GVM follicles. Initial stages } \\
\text { of oocyte maturation may also be present, as well as GVBD follicles. }\end{array}$ \\
Post-spawning & $\begin{array}{l}\text { Post-spawning ovaries show the end of the reproductive period. The "regressing" and "regenerating" stages de- } \\
\text { scribed by Brown-Peterson et al. (2011) are included. Characteristics: POFs and PG oocytes are unorganized in } \\
\text { the ovigerous lamellae, which later organize (constituted of oogonia and PG oocytes; POFs absent). }\end{array}$ \\
\hline
\end{tabular}

Table 2. - Maturation scale of Hypleurochilus fissicornis males in a bivalve cultivation (state of Paraná, Brazil). Adapted from BrownPeterson (2011).

\begin{tabular}{ll}
\hline $\begin{array}{l}\text { Stage of gonadal } \\
\text { development }\end{array}$ & \multicolumn{1}{c}{ Microscopic characteristics } \\
\hline Immature & $\begin{array}{l}\text { Only young males present this stage. The cells of the testicles are the largest among all the stages (spermato- } \\
\text { gonia), distributed uniformly throughout the testicle with no evidence of lumen. }\end{array}$ \\
Developing & $\begin{array}{l}\text { In this stage the fish enters the reproductive cycle, becoming adult. Characteristics: several cell phases are } \\
\text { found in the testicles. The seminiferous tubule is surrounded by larger cells and in the centre (lumen) sper- } \\
\text { matozoa predominate. No one cell type predominates. }\end{array}$ \\
Spawning-capable & $\begin{array}{l}\text { Spermatogonia, spermatocytes and spermatids are still present at the edges of the tubules, but in smaller } \\
\text { quantity, with widening of the central area composed of spermatozoa. Spermatozoa predominate. }\end{array}$ \\
Partially-spawned & $\begin{array}{l}\text { All cell phases are still found surrounding the tubule; however, the centre is found partially empty, with a } \\
\text { smaller number of spermatozoa than in the previous stage. }\end{array}$ \\
Post-spawning & $\begin{array}{l}\text { A stage that shows the end of the reproduction period. It includes the "regressing" and "regenerating" stages } \\
\text { described by Brown-Peterson et al. (2011). The cells are unorganized, with many empty spaces in the tes- } \\
\text { ticles and few or no spermatozoa remaining in the tubules. }\end{array}$
\end{tabular}
ticles and few or no spermatozoa remaining in the tubules.

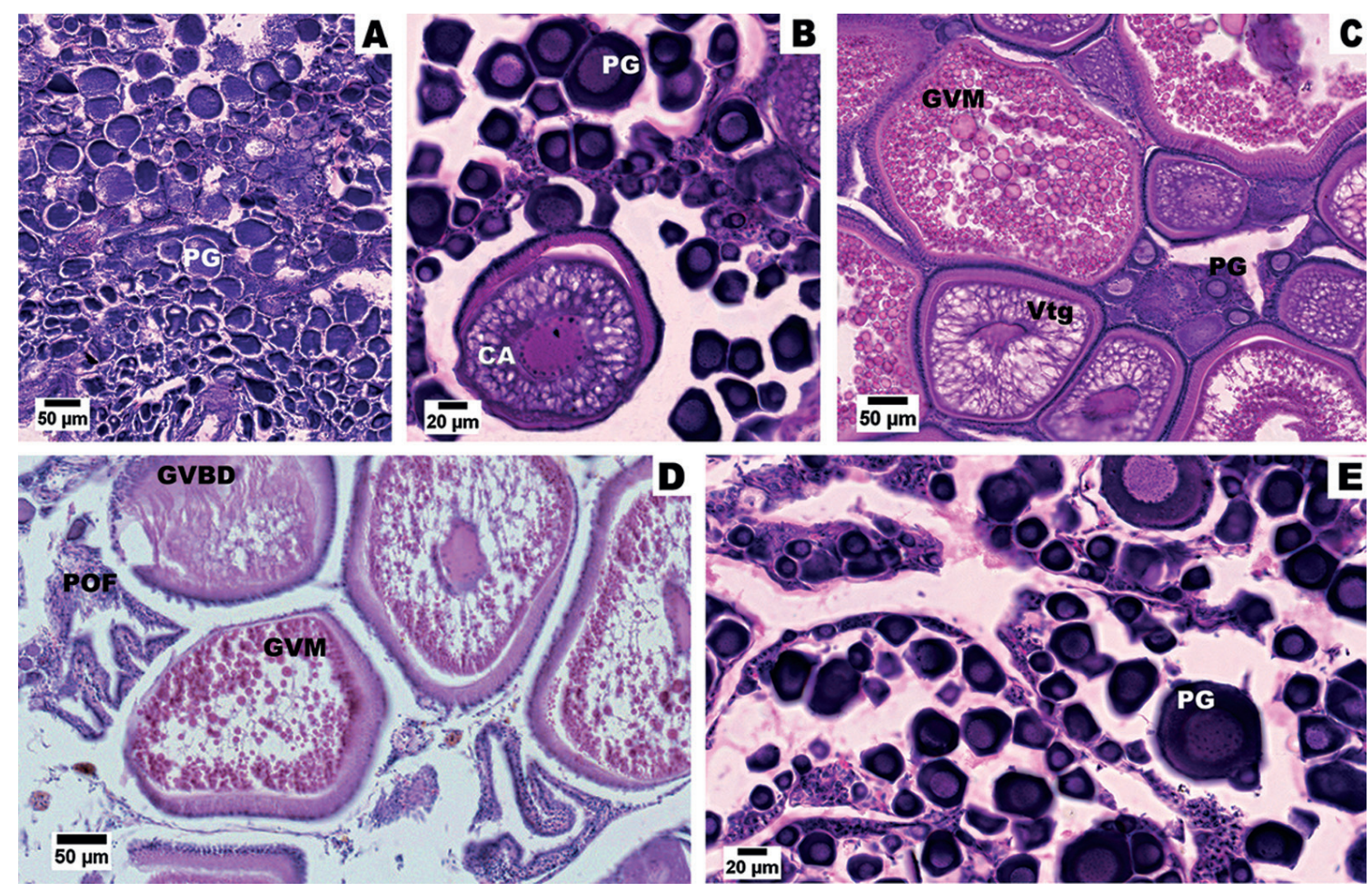

Fig. 3. - Ovarian histology of H. fissicornis. (A) Immature gonad: PG indicates "primary growth oocytes". (B) Development: CA indicates "cortical alveolar oocytes". (C) Spawning-capable: Vtg indicates "vitellogenic oocytes" and GVM indicates "germinal vesicle migration" phase. (D) Partially-spawned: GVBD indicates oocytes in "germinal vesicle breakdown" phase and POF indicates post-ovulatory follicle. (E) Post- spawning gonad. 

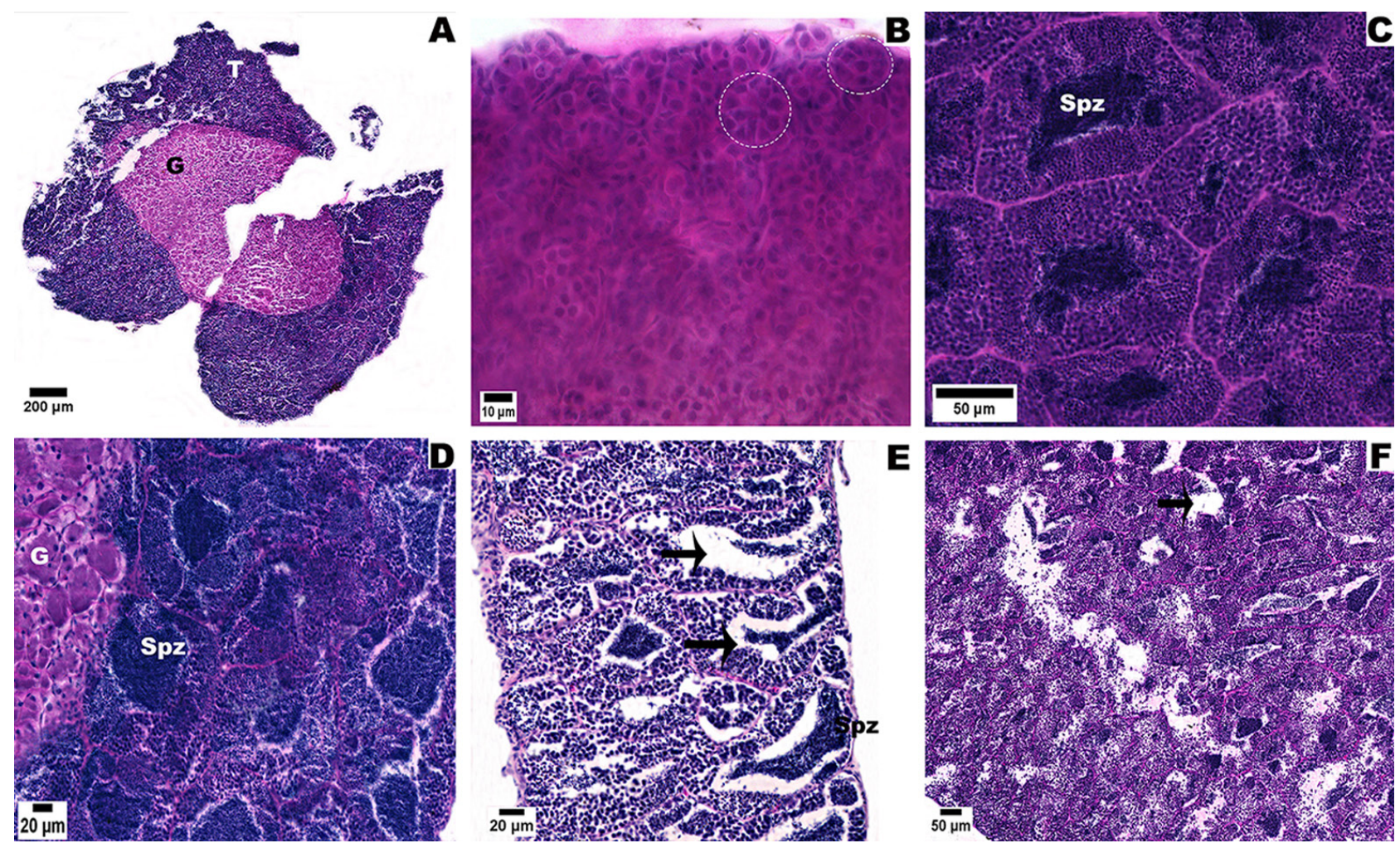

Fig. 4. - Testicles histology of H. fissicornis. (A) Perpendicular histological section of the male gonad showing the testicular gland (G) in the centre and the testicles (T). (B) Immature gonad: circles delimit seminiferous tubules. Note that the cells are large in the male immature gonads. (C) Development: Spz indicates spermatozoa. Note that several cell phases are found in the seminiferous tubule periphery. (D) Spawning-capable: Spz predominate. (E) Partially-spawned: arrows indicate empty spaces due to elimination of spermatozoa. (F) Postspawning gonad: a large number of empty spaces (arrow).

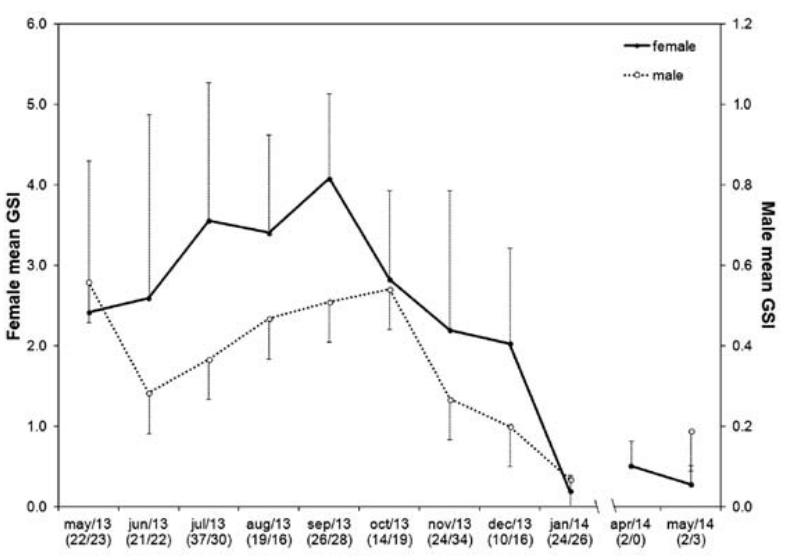

Fig. 5. - Mean monthly Gonadosomatic Index (GSI) with standard deviation of $H$. fissicornis females and males in an oyster cultivation (state of Paraná, Brazil). Numbers in parentheses below the months indicate female/male sampling number. Samples were collected between May/2013 and May/2014. No specimens were caught at the site in February and March 2014.

become cylindrical at the end of oogenesis. The yolk membrane is observed from CA.

The development of sperm cells begins with the spermatogonia (larger volume cell). These cells lose cytoplasmic volume during the mitotic and meiotic cell division, which creates smaller cells with more condensed nuclei that are highly basophilic at each cell division. This results in the formation of spermatozoa (smallest cells from spermatogenesis). Each cell type is

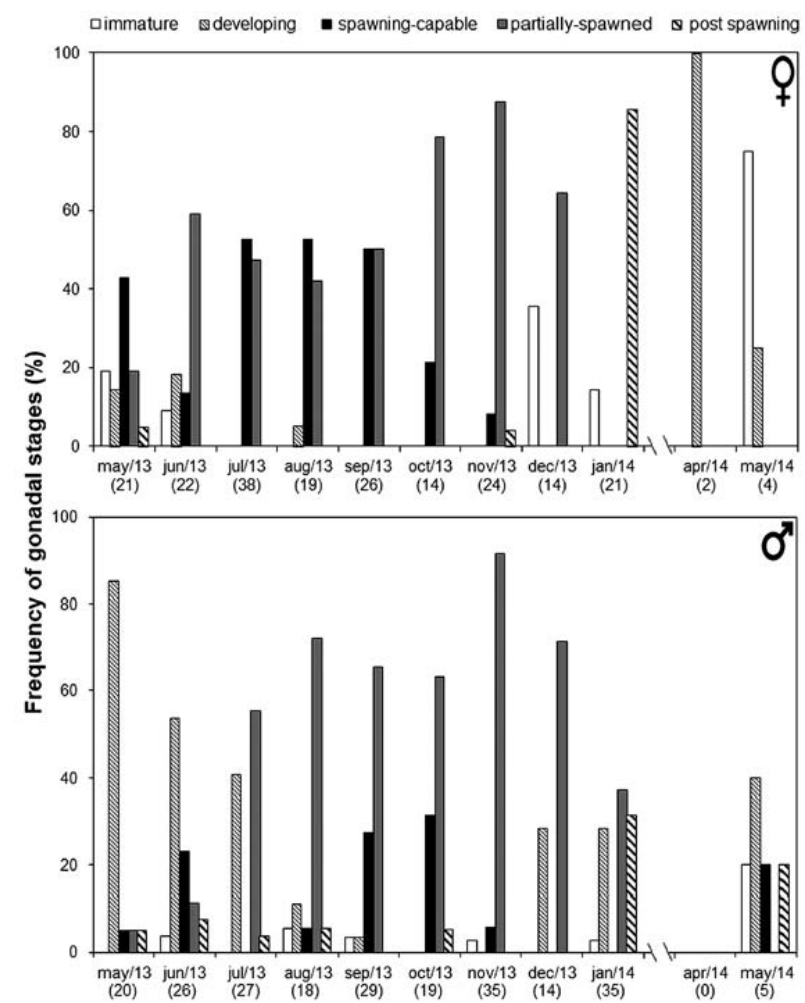

Fig. 6. - Monthly percentage frequency of the maturation stages of the females (above) and males (below) of H. fissicornis in a bivalve cultivation (state of Paraná, Brazil) between May 2013 and May 2014. Numbers in parentheses below the months indicate the sampling number of the month in question. 
arranged radially into clusters, forming the wall of the seminiferous tubules, with the spermatozoa located in the lumen. Testes are located peripherally, surrounding a central portion, the testicular gland.

The gonadal maturity scale (five stages for each sex) was determined from the characterization of the oogenesis and spermatogenesis (Tables 1 and 2, Figs 3 and 4). Partial spawning for the species was characterized by observation of partially-spawned gonads through histological analysis.

\section{Reproduction analysis}

The maturation curve showed a synchronized trend for females and males, characterizing an extensive reproductive period of eight months (May to December) (Fig. 5). Winter was the period with the highest reproductive activity, showing the highest frequencies of spawning-capable gonads (Fig. 6). Partially-spawned individuals were sampled throughout the period, except in January and May 2014, months with smaller mean GSI values and higher frequencies of gonads in the post-spawning and developing stages, respectively. Young individuals were recorded in almost the entire sampling period, but in higher abundance in December, January and May (Fig. 7).

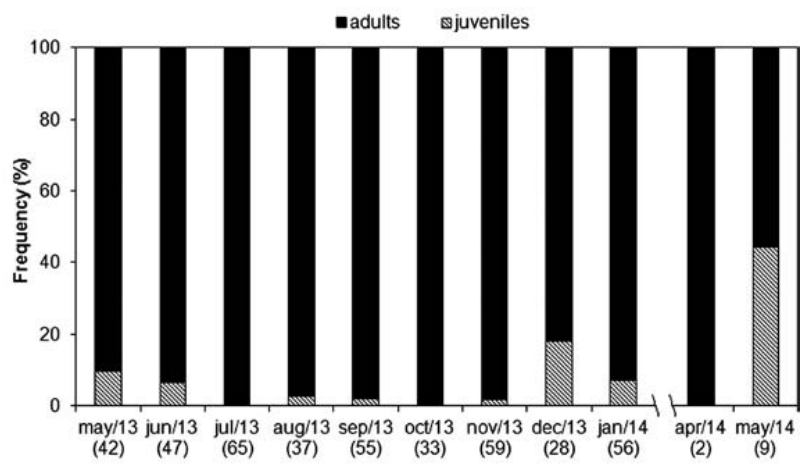

Fig. 7. - Frequency of young and adult individuals of $H$. fissicornis caught in a bivalve cultivation (state of Paraná, Brazil) between May 2013 and May 2014. No individuals were caught in February and March 2014. Numbers in parentheses below the months indicate the total of individuals collected in the month.

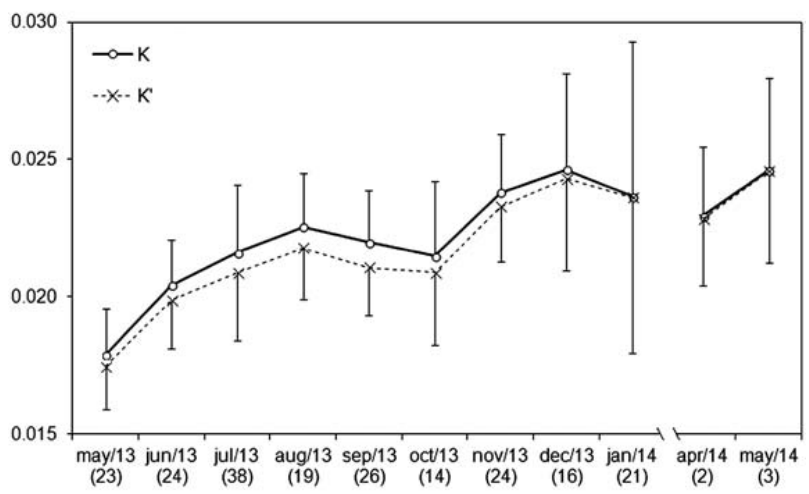

Fig. 8. - Values of the total condition factor $(\mathrm{K})$ and the somatic condition factor ( $\left.\mathrm{K}^{\prime}\right)$, with standard deviation for females of $H$. fissicornis in a bivalve cultivation (state of Paraná, Brazil) between May 2013 and May 2014. No specimens were caught at the site in February and March 2014. Values in parentheses below the months indicate the sampling number of the month in question.
Corroborating the maturation curve and the frequency of gonadal stages, the total $(\mathrm{K})$ and somatic ( $\mathrm{K}^{\prime}$ ) condition factors confirmed the extensive period of investment in gonads, especially for females (Fig. 8). In turn, for males, graphic analysis evidenced no difference, given the small variation in testis weight over the period.

The use of empty oyster shells for spawning was observed from June to November. Shells with spawns
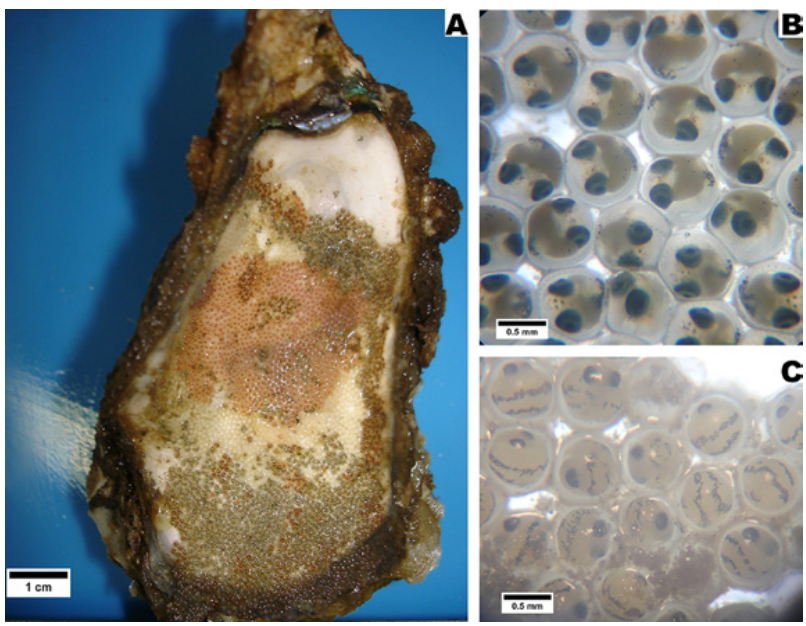

Fig. 9. - In (A) oyster shell with spawning of $H$. fissicornis showing (through staining) different egg development phases. Eggs found in the spawning (right) collected in (B) July 2013 and (C) November

2013 in a cultivation on the coast of the state of Paraná (Brazil).

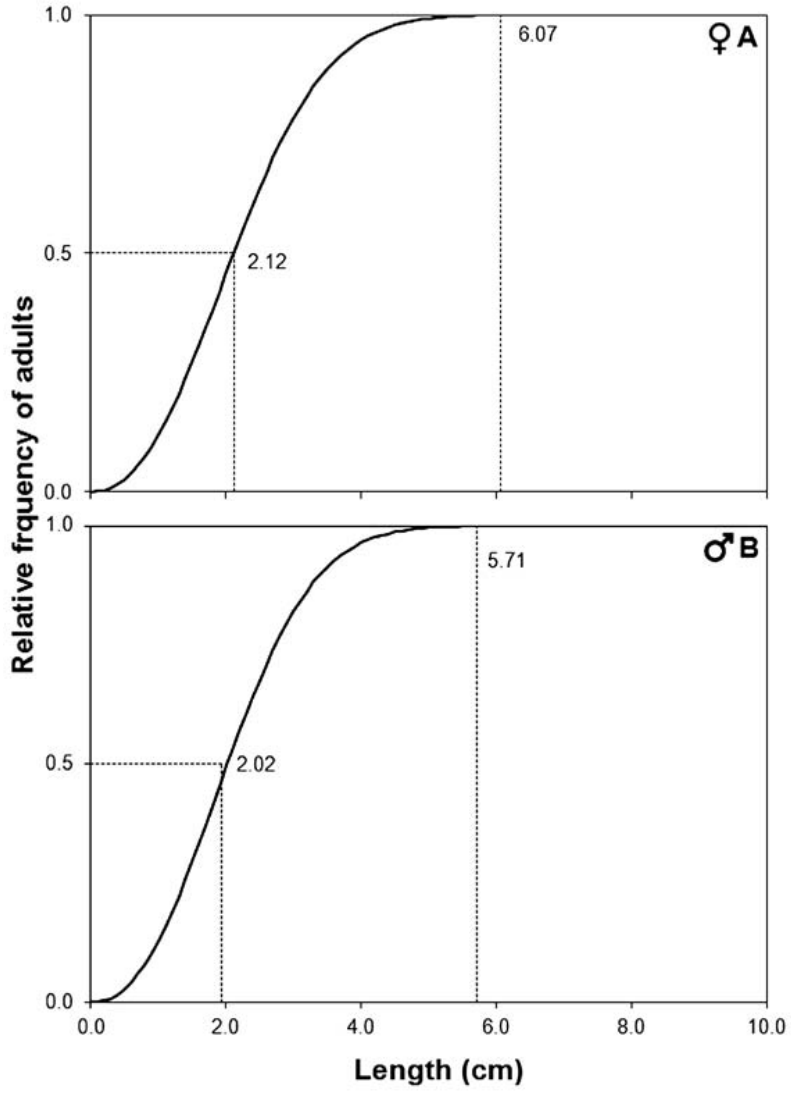

Fig. 10. - First maturation length estimated for females (A) and males (B) of $H$. fissicornis collected in a bivalve collection (state of Paraná, Brazil) between May 2013 and May 2014. 
Table 3. - Eigenvalues and values calculated by the broken-stick method. Abiotic variables are below with their respective contributions to explain the PCA axes. The values of the variables that contributed most to the explanation of the first axis are in bold.

\begin{tabular}{lccccc}
\hline & PC1 & PC2 & PC3 & PC4 & PC5 \\
\hline Eigenvalues & 3.066 & 1.373 & 0.778 & 0.574 & 0.164 \\
Broken-stick & 2.450 & 1.450 & 0.950 & 0.617 & 0.367 \\
\hline \multicolumn{7}{c}{ Variables' contribution to the axes } \\
\hline $\mathrm{T}^{\circ} \mathrm{C}$ water & $\mathbf{1 . 1 0 6}$ & -0.187 & 0.203 & 0.236 & 0.167 \\
Salinity & -0.531 & 0.827 & 0.058 & 0.658 & -0.166 \\
$\mathrm{pH}$ & 0.315 & 0.992 & 0.106 & -0.545 & -0.095 \\
$\mathrm{DO}$ & $\mathbf{- 1 . 0 1 9}$ & -0.412 & -0.225 & -0.109 & -0.142 \\
$\mathrm{~T}^{\circ} \mathrm{C}$ air & $\mathbf{1 . 1 3 4}$ & -0.179 & 0.148 & 0.092 & -0.376 \\
Rainfall & 0.635 & 0.185 & -0.985 & 0.068 & 0.019 \\
\hline
\end{tabular}

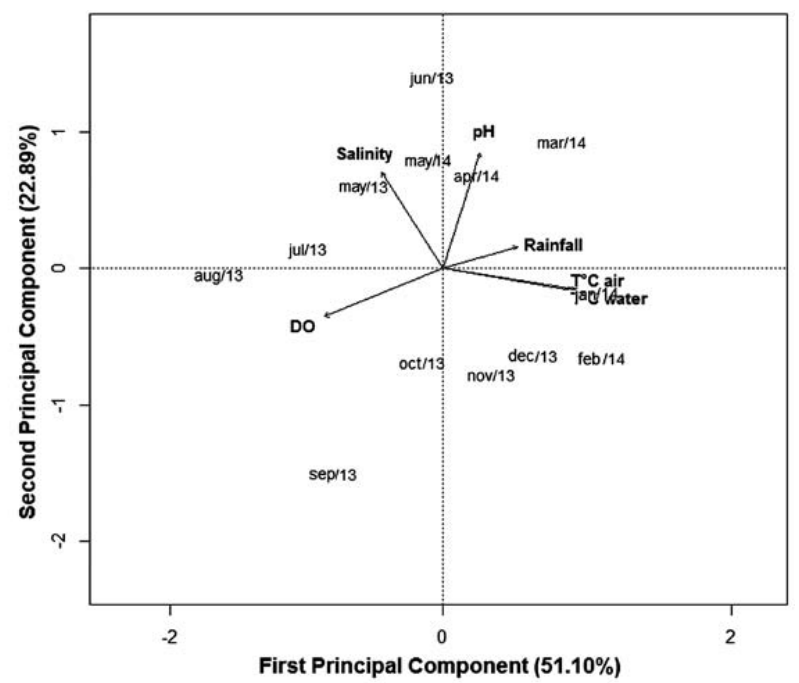

Fig. 11. - Diagram of the principal components analysis for the months of May 2013 to May 2014 in a bivalve cultivation (state of Paraná, Brazil). Vectors represent the sampled abiotic variables. $\mathrm{T}^{\circ} \mathrm{C}$ air and $\mathrm{T}^{\circ} \mathrm{C}$ water (temperature of the air and water, respectively); DO (dissolved oxygen). The percentage of explanation of the axis is between parentheses on the side of the legend.

Table 4. - Result of the Spearman correlations carried out between component 1 of the PCA (representing values of the air and water temperatures and dissolved oxygen) and the monthly frequencies of the maturation stages. Statistically significant values $(\alpha=0.05)$ in

\begin{tabular}{|c|c|c|c|c|}
\hline Stage & \multicolumn{2}{|c|}{ Female } & \multicolumn{2}{|c|}{ Male } \\
\hline Immature & 0.13 & 0.653 & -0.29 & 0.325 \\
\hline Developing & -0.26 & 0.189 & -0.39 & 0.093 \\
\hline Spawning-capable & -0.88 & $<0.001$ & -0.49 & 0.042 \\
\hline Partially-spawned & -0.31 & 0.146 & -0.36 & 0.108 \\
\hline Post-spawning & 0.21 & 0.239 & -0.24 & 0.787 \\
\hline
\end{tabular}

were under the care of a single male of the species, and each nest contained several egg development stages, indicated by their colour (Fig. 9).

The $\mathrm{L}_{50}$ of females was $2.12 \mathrm{~cm}$ and the $\mathrm{L}_{100}$ was $6.07 \mathrm{~cm}$ (Fig. 10A). The estimate for males was $\mathrm{L}_{50}=2.02 \mathrm{~cm}$ and $\mathrm{L}_{100}=5.71 \mathrm{~cm}$ (Fig. 10B).

\section{Relationship between abiotic factors and reproduction}

From June to August, values of water and air temperatures were the lowest, accompanied by the highest DO values. In the study period, salinity varied from 13 to 30 and $\mathrm{pH}$ from 7.05 to 8.19 . Only the first PCA axis was sufficient to represent the data distribution. This axis was very positively influenced by the water and air temperatures and very negatively by DO (Fig. 11; Table 3).

For both female and male individuals, the spawning-capable stage was strongly negatively correlated with the first PCA component, indicating that individuals probably reach maturity at lower temperatures (Table 4).

\section{DISCUSSION}

Females showed an ovarian maturity scale in agreement with the pattern found in other teleosts, while males of $H$. fissicornis had a testicular gland associated with the testis, making the determination of male gonadal development more complex.

Unlike most teleosts, H. fissicornis have testes limited to a reduced peripheral part of the testicular gland, so the developing, spawning-capable and partiallyspawned stages were difficult to characterize because these stages have all types of sperm cells (differing slightly in number of spermatozoa). This partial release of gametes is an important reproductive tactic because it reduces the probability of larval loss due to environmental fluctuations (Santos 1995).

The extensive reproductive period was also found for Coryphoblennius galerita on the Portuguese coast (Almada et al. 1996). However, Blenniidae species on the coast of Portugal and Spain showed a reproductive peak in summer (Almada et al. 1994, Almada et al. 1996, Carrassón and Baú 2003), whereas $H$. fissicornis, in southern Brazil, reaches greater reproductive activity in winter, as gonadal maturity is intimately related to the drop in water temperature. This difference in the reproduction period may be used by the species to avoid potential predators, since as youth of piscivorous fishes (as Epinephelidae) were found in the study area only in summer (personal observation). Other piscivorous fish species, such as Centropomus parallelus and Cynoscion sp., have been found in the surroundings of the study area (Gomes and Chaves 2006, Vendel et al. 2010). In addition, the disappearance of $H$. fissicornis specimens in February and March demonstrates that the bivalve farming is used by the species only as a reproductive site. Therefore, after reproduction, the individuals leave the area, as described for Salaria pavo (Almada et al. 1994). In addition, this behaviour of $H$. fissicornis also avoids predation in summer. 
On the other hand, in colder waters such as those of Argentina, the reproductive period of $H$. fissicornis is in summer (Delpiani et al. 2012), and this situation may indicate that the ideal temperature range for gonadal development and larval development is found in winter in warm waters and in summer in cold waters. Temperature influences the maturation and growth rate of Parablennius ruber, which are accelerated with increasing temperature (Azevedo and Homem 2002). The relationship of temperature, latitude and reproductive period was also demonstrated by Fávaro et al. (2007) for Atherinella brasiliensis.

With regard to the use of empty shells, several egg development stages were observed in the same shell, indicating that more than one female may have used the same nest in different periods, spawning batches of ovarian follicles under the care of a single male. This strategy is used by Rhabdoblennius nitidus females, which choose their partners by preferentially repeating the choice of another female, in order to reduce the probability of desertion of the male (Matsumoto and Takegaki 2013). Considering that the ability of the male to care for the eggs is directly related to the probability of larval survival, subjecting spawns to several partners is advantageous (Santos 1995). Since the males need to defend their nests, their parental care may explain the longer length observed in males.

The species $H$. fissicornis was abundant in the bivalve farming studied, and the presence of young individuals for several months is indicative that the species has been reproductively successful at the site. In marine reef environments, the species is present in low abundances (Luiz-Jr. et al. 2008, Hackradt and FélixHackardt 2009, Alves and Pinheiro 2011), which may indicate that the farms, more sheltered in the estuary, offer greater protection during the reproductive cycle. However, since the samplings of the works cited above were carried out using visual censuses, cryptic and small-sized species can be underestimated (Ackerman and Bellwood 2000).

The highest frequency of young individuals was recorded in December, coinciding with the end of the reproductive season. The largest number of males in relation to females in January possibly indicates that females leave the breeding site earlier, as only males display parental care for the offspring.

The determination of length at first maturity for $H$. fissicornis pointed out that individuals with much reduced length enter into the reproductive process. Based on the $\mathrm{L}_{50} / \mathrm{L}_{\max }$ ratio, the values were 0.27 for the females and 0.23 for the males. This is characterized as an early first maturity, since the value of the $\mathrm{L}_{50} / \mathrm{L}_{\max }$ ratio is generally between 0.4 and 0.9 for different species (Beverton and Holt 1959).

Our results demonstrate that $H$. fissicornis has a variety of tactics to protect its offspring (e.g. batch spawning, long reproductive period, parental care, small length at first maturity and low-temperature reproductive period). Thus, the oyster farm is used as a breeding site by $H$. fissicornis in winter, ensuring the reproductive success of the species.

\section{ACKNOWLEDGEMENTS}

We thank Hamilton de Moura Kirchner for allowing this study in his mariculture, Augusto L. Ferreira Junior for making the map, and Diego Zanlorenzi, Thiago B. Mayer, Gisleine Hoffman, Wanessa P. D. Carmo and all who helped with the sampling. We also thank Coordenação de Aperfeiçoamento de Pessoal de Nivel Superior (CAPES) for the postgraduate scholarship and the Instituto SIMEPAR for the environment data provided.

\section{REFERENCES}

Ackerman J.L., Bellwood D.R. 2000. Reef fish assemblages: a reevaluation using enclosed rotenone stations. Mar. Ecol. Prog. Ser. 206: 227-237.

http://dx.doi.org/10.3354/meps206227

Almada V.C., Gonçalves E.J., Santos A.J., et al. 1994. Breeding ecology and nest aggregations in a population of Salaria pavo (Pisces: Blenniidae) in an area where nest sites are very scarce. J. Fish Biol. 45: 819-830. http://dx.doi.org/10.1111/j.1095-8649.1994.tb00947.x

Almada V.C., Carreiro H., Faria C., et al. 1996. The breeding season of Coryphoblennius galerita in Portuguese waters. J. Fish Biol. 48: 295-297. http://dx.doi.org/10.1111/j.1095-8649.1996.tb01121.x

Alves J.A., Pinheiro P.C. 2011. Peixes recifais das ilhas costeiras do Balneário Barra do Sul - Santa Catarina - Brasil. R. CEPSUL Biodiv. Conserv. Mar. 2(1): 10-21.

Azevedo J.M.N., Homem N. 2002. Age and growth, reproduction and diet of the red blenny Parablennius ruber (Blenniidae). Cybium. 26(2): 129-133.

Beverton R.J.H., Holt S.J. 1959. A review of the lifespans and mortality rates of fish in nature, and their relation to growth and other physiological characteristics. In: Wolstenholme G. E. W., Oconnor M. (eds), Ciba Foundation Colloquia on Ageing. 5: 142-180.

http://dx.doi.org/10.1002/9780470715253.ch10

Brotto D.S., Krohling W., Zalmon I.R. 2007. Comparative evaluation of fish assemblages census on an artificial reef. Rev. Bras. Zool. 24(4): 1157-1162 http://dx.doi.org/10.1590/S0101-81752007000400037

Brown-Peterson N.J., Wyanski D.M., Saborido-Rey F., et al. 2011. A Standardized Terminology for Describing Reproductive Development in Fishes. Mar. Coast. Fish. Dynam. Manag. Ecosys. Sci. 3(1): 52-70 http://dx.doi.org/10.1080/19425120.2011.555724

Carrassón M., Baú M. 2003. Reproduction and gonad histology of Aidablennius sphynx (Pisces: Blenniidae) of the Catalan Sea (northwestern Mediterranean). Sci. Mar. 67(4): 461-469 http://dx.doi.org/10.3989/scimar.2003.67n4461

Delpiani S.M., Bruno D.O. Díaz De Astarloa J.M., et al. 2012. Development of early life stages of the blenny Hypleurochilus fissicornis (Blenniidae). Cybium. 36(2): 357-359.

Fávaro L.F., Lopes S.C.G., Spach H.L. 2003. Reprodução do peixe-rei, Atherinella brasiliensis (Quoy \& Gaimard) (Atheriniformes, Atherinidae), em uma planície de maré adjacente à gamboa do Baguaçu, Baía de Paranaguá, Paraná, Brasil. Rev. Bras. Zool. 20: 501-506. http://dx.doi.org/10.1590/S0101-81752003000300022

Fávaro L.F., Oliveira E.C., Verani N.F. 2007. Estrutura da população e aspectos reprodutivos do peixe-rei Atherinella brasiliensis (Quoy \& Gaimard) (Atheriniformes, Atherinopsidae) em áreas rasas do complexo estuarino de Paranaguá, Paraná, Brasil. Rev. Bras. Zool. 24(4): 1150-1156. http://dx.doi.org/10.1590/S0101-81752007000400036

Floeter S.R., Gasparini J.L., Rocha L.A., et al. 2003. Brazilian reef fish fauna: checklist and remarks (updated Jan. 2003). Brazilian Reef Fish Project: www.brazilianreeffish.cjb.net.

Freitas M.O., Velastin R. 2010. Ictiofauna associada a um cultivo de mexilhão Perna perna (Linnaeus, 1758) Norte Catarinense, Sul do Brasil. Acta Sci. Biol. Sci. 32(1): 31-37. http://dx.doi.org/10.4025/actascibiolsci.v32i1.2515

Gerhardinger L.C., Hostim-Silva M., Barreiros J.P. 2004. Empty mussel shells on mariculture ropes as potential nest places for 
the blenny Hypleurochilus fissicornis (Perciformes: Blenniidae). J. Coast. Res. SI39: 1202-1204.

Gomes I.D., Chaves P.T. 2006. Ictiofauna integrante da pesca de arrasto no litoral sul do estado do Paraná. Bioikos 20(1): 9-13.

Goodbrand L., Abrahams M.V., Rose G.A. 2013. Sea cage aquaculture affects distribution of wild fish at large spatial scales. Can. J. Fish. Aquat. Sci. 70(9): 1289-1295. http://dx.doi.org/10.1139/cjfas-2012-0317

Granneman J.E., Steele M.A. 2014. Fish growth, reproduction, and tissue production on artificial reefs relative to natural reefs. ICES J. Mar. Sci. 71: 2494-2504 http://dx.doi.org/10.1093/icesims/fsu082

Hackradt C.W., Félix-Hackradt F.C. 2009. Assembléia de peixes associados a ambientes consolidados no litoral do Paraná, Brasil: Uma análise qualitativa com notas sobre sua bioecologia. Pap. Avulsos de Zool. 49(31): 389-403.

Le Cren E.D. 1951. The length-weight relationship and seasonal cycle in gonad and conditions in the perch Perca fluviatilis. $\mathrm{J}$. Anim. Ecol. 20(2): 201-219. http://dx.doi.org/10.2307/1540

Lowerre-Barbieri S.K., Brown-Peterson N.J., Murua H., et al. 2013. Emerging issues and methodological advances in fisheries reproductive biology. Mar. Coast. Fish. Dynam. Manag. Ecosys. Sci. 3(1): 32-51. http://dx.doi.org/10.1080/19425120.2011.555725

Luiz-Jr O.J., Carvalho-Filho A., Ferreira C.E.L., et al. 2008. The reef fish assemblage of the Laje de Santos Marine State Park, Southwestern Atlantic: annotated checklist with comments on abundance, distribution, trophic structure, symbiotic associations, and conservation. Zootaxa 1807: 1-25.

Matsumoto Y., Takegaki T. 2013. Female mate choice copying increases egg survival rate but does not reduce mate-sampling cost in the barred-chin blenny. Anim. Behav. 86: 339-346. http://dx.doi.org/10.1016/j.anbehav.2013.05.024
Menezes N.A., Figueiredo J.L. 1985. Manual de peixes marinhos do sudeste do Brasil - V Teleostei (4). Museu de Zoologia. Univ. São Paulo. São Paulo, pp. 54-55.

Oliveira E.C., Fávaro L.F. 2011. Reproductive biology of the flatfish Etropus crossotus (Pleuronectiformes: Paralichthyidae) in the Paranaguá Estuarine Complex, Paraná State, subtropical region of Brazil. Neotrop. Ichth. 9: 795-805. http://dx.doi.org/10.1590/S1679-62252011005000043

Omena E.P., Souza M.M. 1999. Efeito da predação no desenvolvimento inicial da comunidade incrustante na região da Urca, Baía de Guanabara, RJ. Oecol. Bras. 7: 213-227. http://dx.doi.org/10.4257/oeco.1999.0701.10

Santos R.S. 1995. Anatomy and histology of secondary sexual characters, gonads and liver of the rock-pool blenny, Parablennius sanguinolentus parvicornis, (Pisces: Blenniidae) of the Azores. Arquipel. Life Mar. Sci. 13(A): 21-38.

Santos R.S., Porteiro F.M., Barreiros J.P. 1997. Marine fishes of the Azores: annotated checklist and bibliography. Bull. Univ. Azores Suppl: 1: 1-244.

Sokal R.R., Rohlf F.J. 1981. Biometry. W. H. Freeman. New York, $859 \mathrm{pp}$.

Thrush S.F. Dayton P.K. 2002. Disturbance to marine benthic habitats by trawling and dredging: Implications for Marine Biodiversity. Annu. Rev. Ecol. Syst. 33: 449-473. http://dx.doi.org/10.1146/annurev.ecolsys.33.010802.150515

Vazzoler A.E.M. 1996. Biologia da reprodução de peixes teleósteos: teoria e prática. EDUEM. Maringá, 169 pp.

Vendel A.L., Bouchereau J.L., Chaves P.T. 2010. Environmental and subtidal fish assemblage relationships in two different Brazilian coast estuaries. Braz. Arch. Biol. Technol. 56(6): 1393-1406.

http://dx.doi.org/10.1590/S1516-89132010000600016 